\title{
WEB-Based Village Application at Singabangsa's Village Head Office
}

\author{
Andri Cahyo Purnomo ${ }^{* 1}$, Hardikan Arief Nugraha Sofyan ${ }^{2}$, Febian Hendra Saputra ${ }^{3}$ \\ ${ }^{1,2,3}$ Fakultas Sains \& Technology University of Raharja \\ E-mail: ${ }^{* 1}$ andricahyo@ raharja.info, ${ }^{2}$ hardikan@ raharja.info, ${ }^{3}$ febian.hendra@ raharja.info
}

\begin{abstract}
The Application of Information Technology currently has been spread almost in all areas of administrative management is no exception At the head office of the village. However, the information and data archiving service of the resident at the Singabangsa Village Head Office which is still manual, resulted in the ineffectiveness of information can be submitted to the community and the slow pace of population data collection. Public Information needs and The enormous population growth makes the researcher aim to design a village information system that can deliver efficient and accurate population data and easy in updating data. To overcome the above problems it is necessary an automation system capable of providing village information services and population data which are classified according to category until can be calculated statistically quickly, accurately and efficiently. The purpose of this village information system to optimize information services by providing village information and population that can be accessed easily with precise and accurate. In this research the researcher applies research method in the form of observation method, interview, study literature, SWOT analysis, system analysis and system design. This system is designed by using PHP programming language as well as MySQL database. Benefits and advantages in the use of village-based information system (SID) is the process of information services can be done easily and search data demographics more accurate and faster. The final result of this research is a web village information system design (SID).
\end{abstract}

Keywords — Information Services, SWOT, MySQL, PHP

\section{INTRODUCTION}

Along with the development of science and technology, making information has a very important role in efforts to create progress in all fields of human life. With the existence of information technology, it has been felt a lot easier to get information that is fast, precise and accurate.

It can be estimated that all agencies, both State and Private, have used computer systems for the need for more effective and efficient data and information. But in fact not all companies or government agencies, especially at the village level have realized the benefits of more than a well-computerized information system. Because there are several varied obstacles such as lack of allowances and available facilities and human resources. So as to make the public service process less than optimal and information can not be given quickly and evenly across all classes of society.

As in the Singabangsa Village Office, which is the lowest level government agency with the intensity of communication with the community is more dominant than the above government agencies. However, the current information service process has not been able to get maximum results because it is still done manually with conventional administrative levels, thus making the level of efficiency and effectiveness of its services become weak. Information is hampered and cannot be received evenly by the community because of the lack of available resources and facilities that can sustain the task of the village administration in the information service process. 
With the problems faced above, researchers feel interested in raising issues in the thesis research entitled "WEB-BASED VILLAGE APPLICATION AT SINGABANGSA'S VILLAGE HEAD OFFICE".

\section{RESEARCH METHOD}

\subsection{Method of Colleting Data}

Data collection methods used in the study consisted of the following steps:

\section{Observation Method}

It is a method of collecting data through direct observation or careful and direct observation in the field or research location. This research was conducted at the Head Office of Singabangsa Village, Tenjo District, Bogor Regency, which is the location of the study in order to obtain data and information relating to the type of research.

\section{Interview Method}

In this method the researcher conducted a question and answer process to Mr. Abdul Haris as the resource person on the research object, namely the Office of the Singabangsa Village Head. In this case the question and answer process is carried out directly to the drafters who are also stakeholders.

\section{Library Study Methods}

Literature study is all efforts made by researchers to obtain and collect all written information that is relevant to the problem under study. This information is obtained from books, research reports, theses / dissertations, regulations, regulations and other sources.

\subsection{Analysis Method}

Data analysis is used to obtain the data needed in the preparation of the report, in this case the data analysis uses the SWOT analysis method (Strengths, Weaknesses, Opportunities, Threat). SWOT analysis is a method used to see the condition of the Village Head's Office and his own village both internal and external which then becomes an indicator to determine the strengths, weaknesses, opportunities and threats to the Village and Village Head's Office, so that it can help in making decisions.

\subsection{Design Methods}

The design method chosen by the author in this thesis research is UML (Unified Modeling Language). By using tools in the form of Visual Paradigm for uml 6.4 enterprise edition, including those used Use Case Diagrams, Class Diagrams, Activity Diagrams, Sequence Diagrams. The design method that will be applied is designing a Website using Notepad ++ to support the ease of the design process, and for storing data using Mysql as a database tool for all information to be displayed

\subsection{Testing Methods}

In testing the software in this study using the black box method because the black box can find out whether the software made can function correctly and is as expected. This testing method is used to analyze a system identity to detect, evaluate conditions and features desired and find out the quality of a system that is done to minimize errors that occur when the system is applied. 


\subsection{Literature Review}

Many previous studies were conducted on village information systems. In the effort to develop this village information system, a literature study as one of the applications of the village information system in the Singabangsa village office will be carried out. Among them are identifying gaps (avoiding gaps), avoiding remaking (reinventing the wheel), identifying researches that have been carried out, continuing previous research, and knowing others who specialize and the same research area in this field. Some of the review literature is as follows:

1. Mubarok, et al (2015) "LEGAL BASIS AND THE ACCORDANCE OF VILLAGE OPENING WITH THE VILLAGE-BASED VILLAGE INFORMATION SYSTEM BASED ON OPEN GOVERNMENT DATA BASED". "Creating schemes / guidelines for villages for the development of village information systems. including the development of the system so that it can be integrated, and the possibility of developing the village information system into a village information system network. Village information system with guidelines on village openness to foster public trust through the characteristics of transparency, participation and collaboration.

2. Erlin Herlian (2014) "DESIGNING POPULATION DATA INFORMATION SYSTEM IN KELURAHAN KUTABARU TANGERANG DISTRICT WEB-BASED". "This study aims to serve and assist the needs of the people of Kutabaru Kelurahan and provide population information, make it easier in the process of making an application for making an E-KTP, Family Card and Moving Cover Letter so that it is more effective and efficient.

3. Abbas, et al (2016) "DESIGN OF E-GOVERNMENT BASED DISTRICT INFORMATION SYSTEM". "realizing population administration services and civil registration oriented to the satisfaction and partnership of the community towards the creation of accurate population data and information and in order to realize the creation of good governance. Integrated e-Government in order to realize good governance and provide satisfaction to the community.

4. Ramadhani, et al (2015) "DEVELOPMENT OF INTEGRATED VILLAGE INFORMATION SYSTEM BASED ON WEB APPLICATION IN SIDAKANGEN VILLAGE, KAB. PURBALINGGA". "The introduction of technology in the community so that the movement of information is spread evenly in the community. Digitize data to be processed so as to improve efficiency in the distribution process. Equalization of the benefits of technology to disseminate information quickly and accurately.

5. Sugianur, Yuli Nurcahyanti (2017) "GANEPO VILLAGE POPULATION INFORMATION SYSTEM BASED ON DEXTS". "Creating a population data collection system that can provide storage and reports quickly and accurately. Provide processing of population data reports in the form of, population data reports, KK data, birth data, death data, moving data, migrant data Population service information system and storage of reports quickly and accurately.

6. Seetharaman, Priya. (2017). "TECHNOLOGY GOVERNANCE CHALLENGES IN EGOVERNMENT PROJECTS: HEALTH INFORMATION SYSTEMS IN INDIA". "This study aims to highlight the need for more conscious effort to anticipate and overcome the challenges of information technology governance in the context of egovernment. IT governance in the context of interim e-government, secondary data on Health Management Information System projects in India.

7. Arif Setiawan and Dedi Irawan. (2017). "IMPLEMENTATION OF E-GOVERMENT AS AN EFFORTS TO IMPROVE VILLAGE POTENTIAL IN SUKOHARJO". "The realization of a government data processing system and the potential of a better and more integrated village because the current system is still manual so that it requires better information processing. "Implementation of E-Government as an effort to increase the potential of villages in the village of Sukoharjo" is used as a solution to replace the system that has been running manually and implemented in Sukoharjo Village with a web-based application system. 


\section{RESULTS AND DISCUSSION}

\subsection{Swot and Analysis}

Analysis to look for strategies using existing strengths to take advantage of available opportunities (S-O strategies) and use their strengths to overcome existing threats (S-T strategies). In addition, also analyzed strategies to reduce the weaknesses that have in seizing opportunities that exist (W-O strategy) and overcome the existing threats (W-T strategy). Mapping strategy S-O, W-O, S-T and W-T can be seen in the following table 3.1:

\begin{tabular}{|c|c|}
\hline Strength & Weakness \\
\hline 1. strategic location & 1. the service process is still manual \\
\hline 2. good office conditions & 2. lacking resources \\
\hline $\begin{array}{l}\text { 3. active community activity } \\
\text { program }\end{array}$ & $\begin{array}{l}\text { 3. irregular placement of data and } \\
\text { documents }\end{array}$ \\
\hline
\end{tabular}

\begin{tabular}{|c|c|c|c|}
\hline \multicolumn{2}{|r|}{ Oppotunity } & Strategy S O & Strategy W O \\
\hline & $\begin{array}{l}\text { support from the } \\
\text { village office }\end{array}$ & $\begin{array}{l}\text { 1. } \text { designing } \\
\text { information systems, } \\
\text { especially in the } \\
\text { process } \\
\text { information service } \\
\text { to the public }\end{array}$ & $\begin{array}{ll}1 . & \text { optimizing } \\
\text { existing } \\
\text { technological } \\
\text { devices }\end{array}$ \\
\hline & $\begin{array}{l}\text { legal basis of } \\
\text { district government } \\
\text { regulations } \\
\text { governing } \\
\text { technology } \\
\text { development } \\
\text { villages }\end{array}$ & $\begin{array}{l}\text { 2. designing a village } \\
\text { information system } \\
\text { that brings the } \\
\text { community closer to } \\
\text { the government }\end{array}$ & $\begin{array}{l}\text { 2. designing data } \\
\text { and information } \\
\text { processing } \\
\text { systems } \\
\text { properly }\end{array}$ \\
\hline & $\begin{array}{l}\text { the needs of the } \\
\text { community are so } \\
\text { high }\end{array}$ & $\begin{array}{l}\text { 3. manage data and } \\
\text { information so that it } \\
\text { can be felt by the } \\
\text { community fairly }\end{array}$ & $\begin{array}{l}\text { 3. using the mysql } \\
\text { database to } \\
\text { build a data } \\
\text { information } \\
\text { system }\end{array}$ \\
\hline
\end{tabular}




\begin{tabular}{|c|c|c|c|}
\hline Threats & Strategy S T & & Strategy W T \\
\hline $\begin{array}{l}\text { 1. the } \\
\text { informatio } \\
\mathrm{n} \text { does not } \\
\text { reach the } \\
\text { public }\end{array}$ & $\begin{array}{l}\text { 1. create a village } \\
\text { information system } \\
\text { that can attract } \\
\text { people to use }\end{array}$ & & $\begin{array}{l}\text { introducing an easily } \\
\text { accessible web-based } \\
\text { village information } \\
\text { system }\end{array}$ \\
\hline $\begin{array}{l}\text { 2. lack of } \\
\text { education } \\
\text { and } \\
\text { training on } \\
\text { the use of } \\
\text { village } \\
\text { informatio } \\
\text { n systems }\end{array}$ & $\begin{array}{l}\text { 2. utilize social media } \\
\text { as a third party for } \\
\text { notification of } \\
\text { information delivery }\end{array}$ & 2. & $\begin{array}{l}\text { guarantee the } \\
\text { authenticity of an } \\
\text { information data and } \\
\text { verify the truth of the } \\
\text { news to be delivered }\end{array}$ \\
\hline 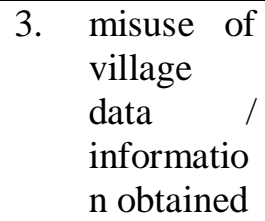 & $\begin{array}{l}\text { 3. create a complex } \\
\text { village information } \\
\text { system so that it is easy } \\
\text { to understand in the } \\
\text { process of use }\end{array}$ & 3. & $\begin{array}{l}\text { adding an antivirus } \\
\text { minimizes the loss of } \\
\text { data on the computer }\end{array}$ \\
\hline
\end{tabular}

\subsection{Display Application on Singabangsa's Village Head Office}

1) Front end view on the homepage

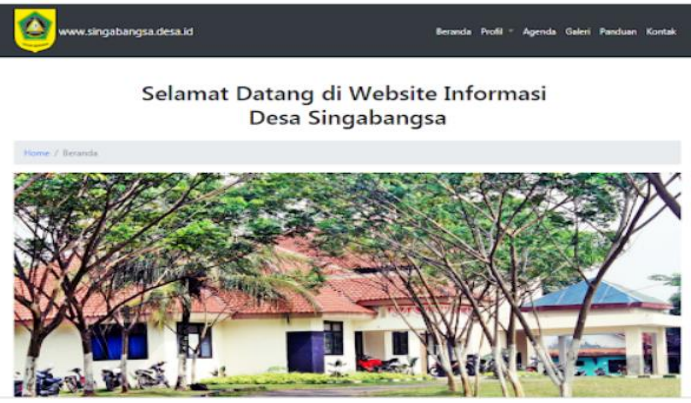

Figure 1. Home page

2) Front end view in the Photo Gallery menu

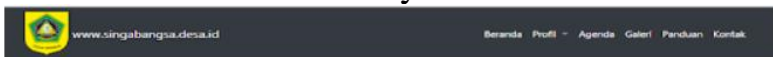

Galeri dan Dokumentasi Desa

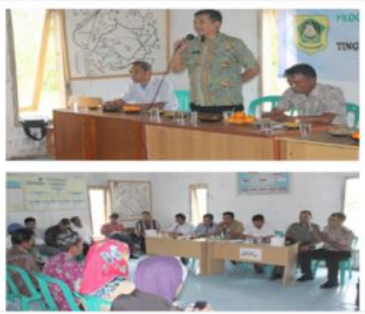

Figure 2. Gallery Menu 
3) Front end view on the Village Profile menu

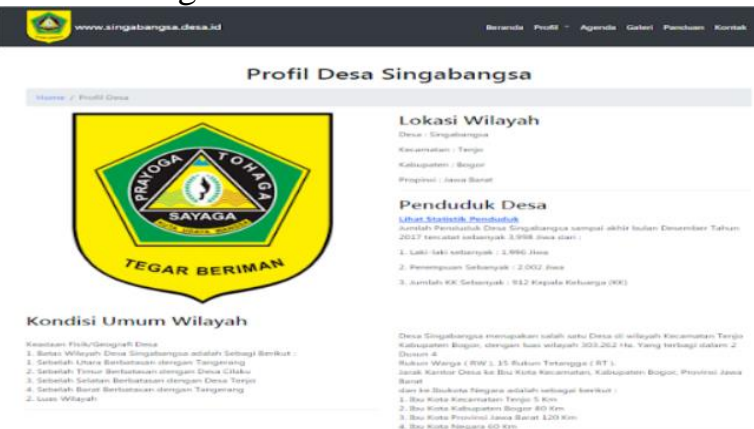

Figure 3. Profile menu

4) Front end view on the Population Statistics menu

\section{Q. minsingatangsadesaid}

Data Statistik Penduduk Berdasarkan Kategori

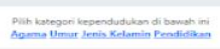

Kategori Umur

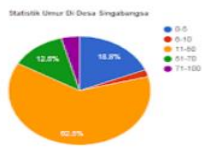

Figure 4. Statistics menu

5) Front end view on the Village Governance Profile menu

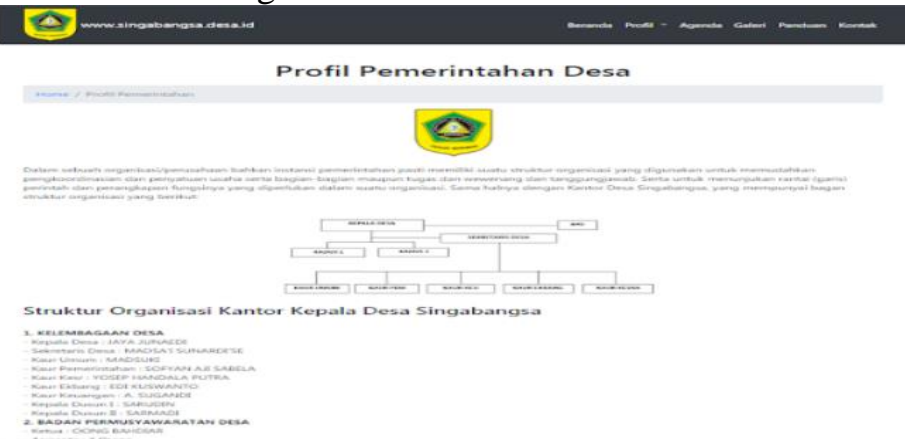

Figure 5. Governance Profile menu

6) Front end view on the Village Agenda menu

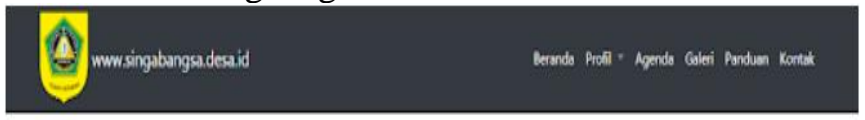

Agenda Desa Tahun 2018

Penyuluhan GapokTan

PEMBAGIAN SEMBAKO

Figure 6. Village Agenda menu 
7) Front end display on the Contacts, Critics and Suggestions menu

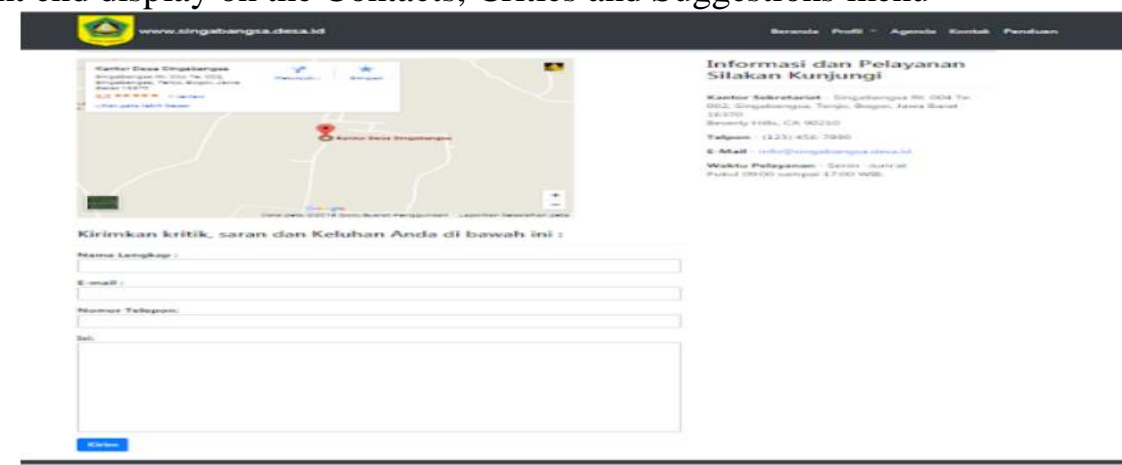

Figure 7. Critics and Suggestions menu

8) Front end view on the Guide menu

Q. mum singabangsadesaid

Panduan Administrasi Penduduk

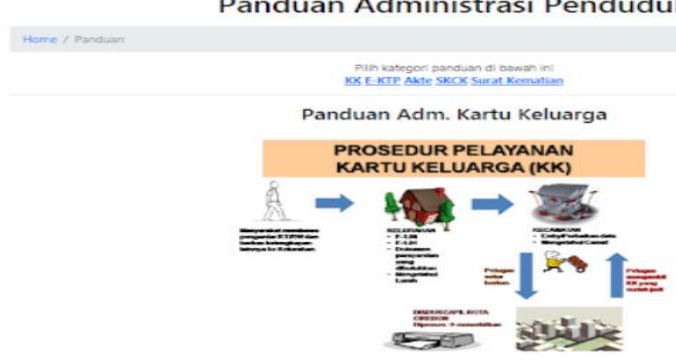

Figure 8. Guide menu

9) Display Dashboard menu on login

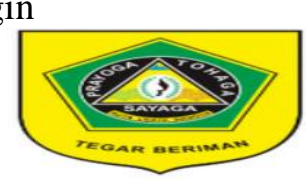

Login Sistem Desa Singabangsa

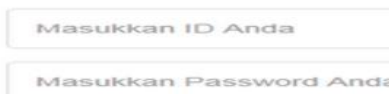

Figure 9. Menu on login 
10) Display Dashboard menu on Home admin

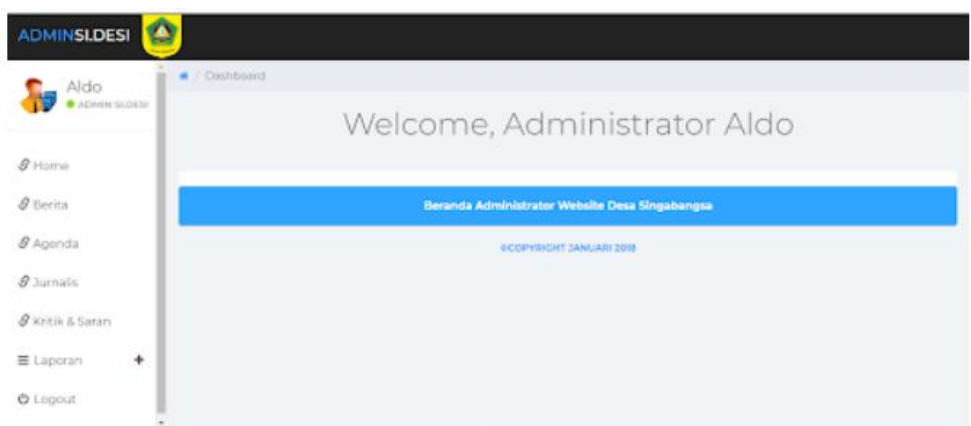

Figure 10. Home admin

11) Display Dashboard on the Admin News menu

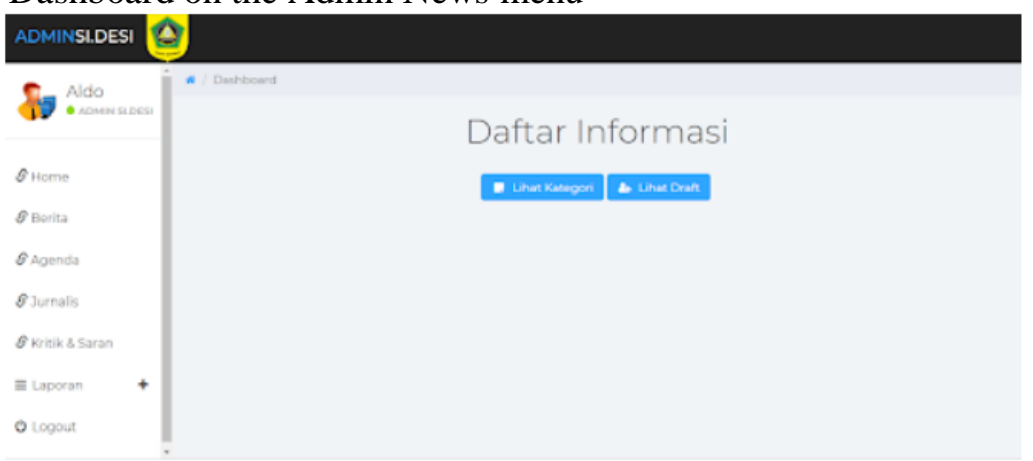

Figure 11. Admin News menu

12) Display Dashboard on the Admin News Categories menu

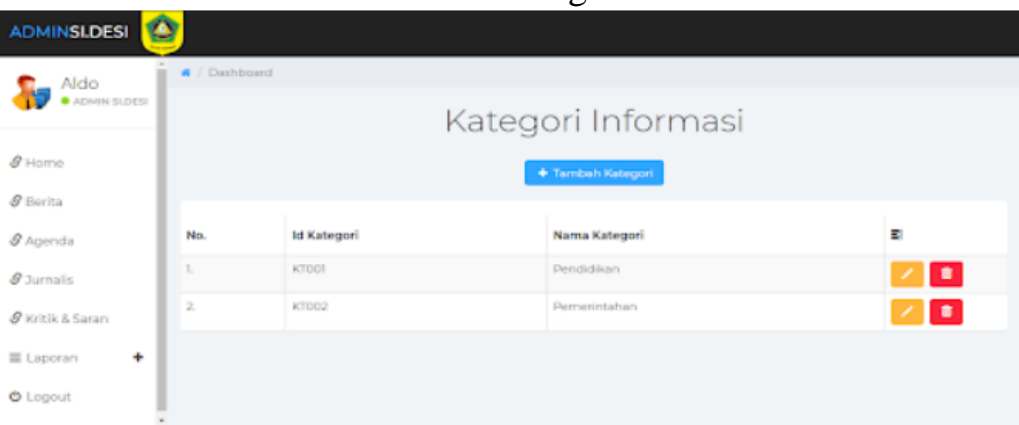

Figure 12. News Categories menu

13) Display Dashboard on the Admin News Draft menu

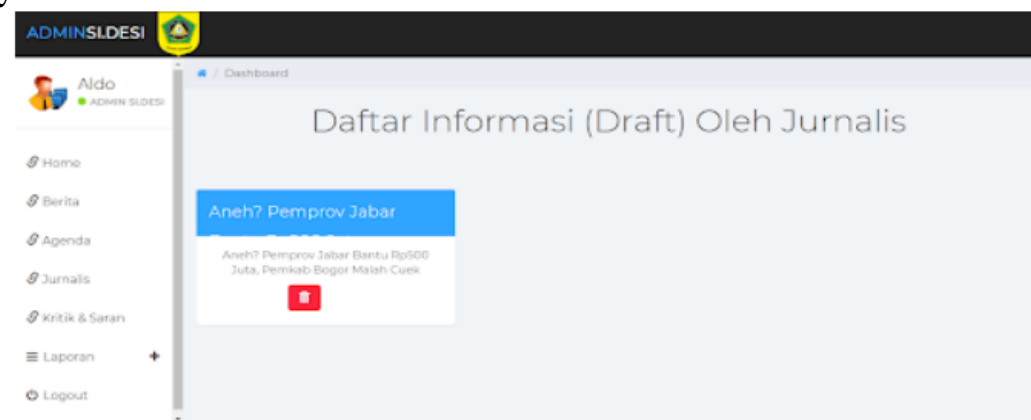

Figure 13. Admin News Draft menu 
14) Display Dashboard on the Publish News Admin menu

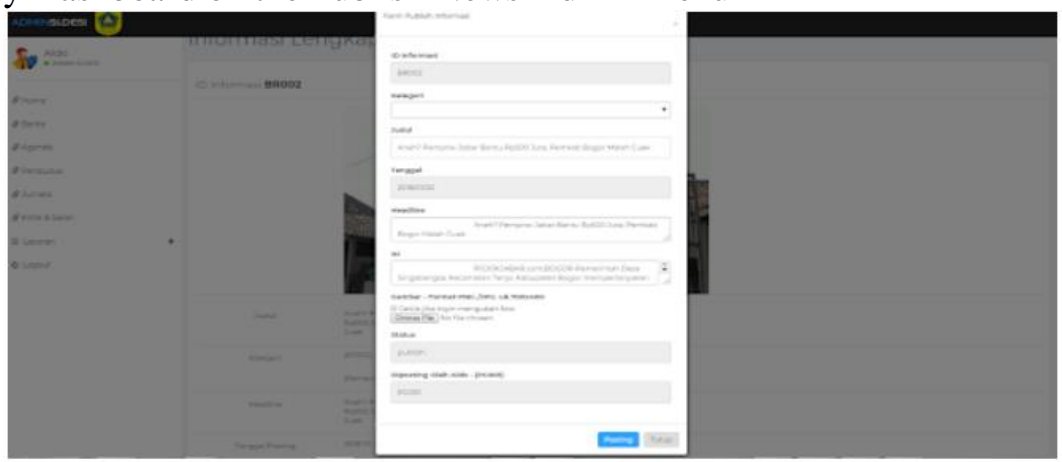

Figure 14. Publish News Admin menu

15) Display Dashboard print resident Admin report

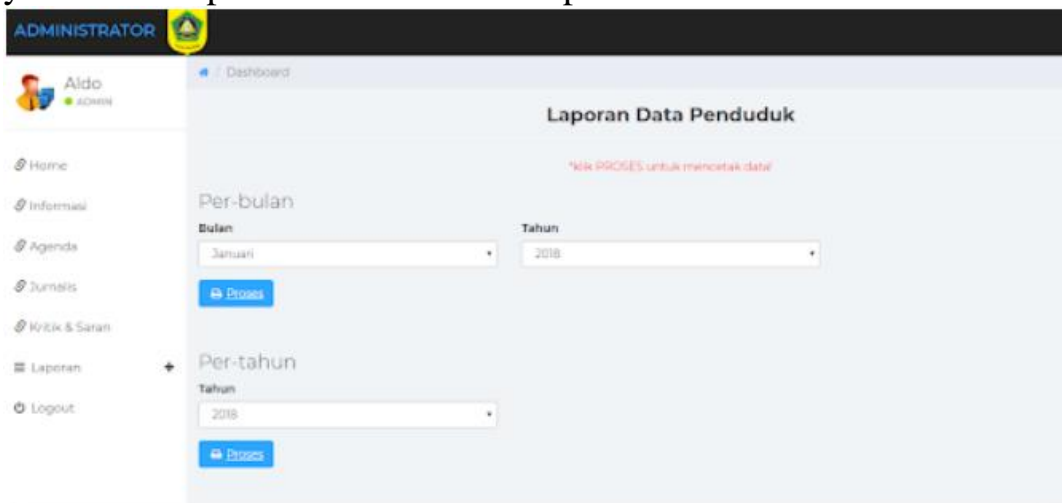

Figure 15. Admin report

16) Display Dashboard print Admin News report

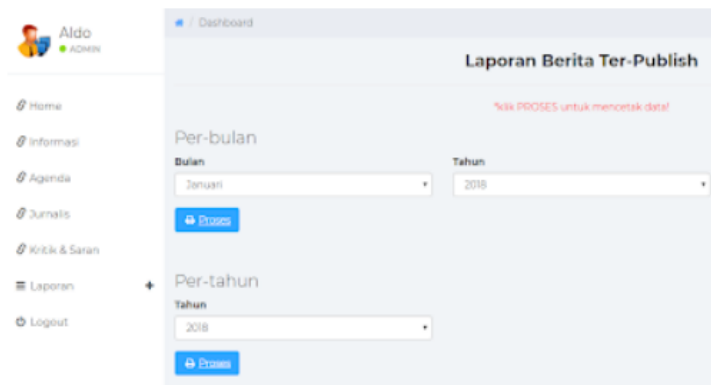

Figure 16. Admin News report

17) Display Dashboard on the Admin Village Agenda menu

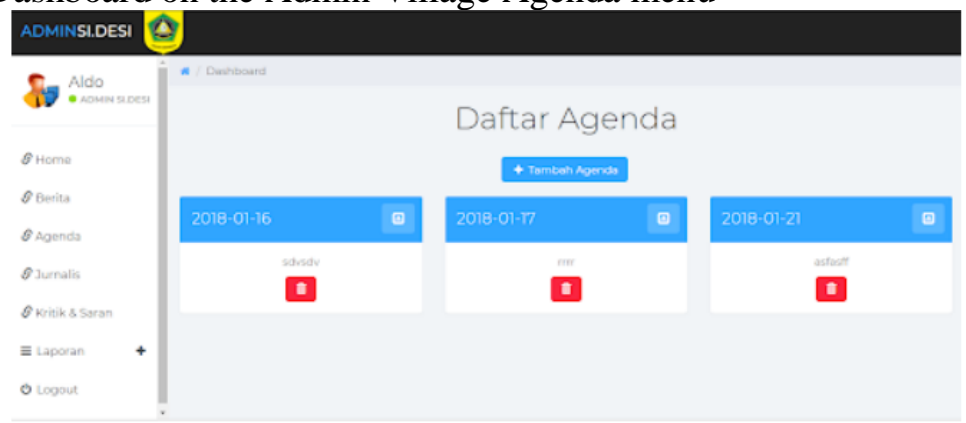

Figure 17. Admin Village Agenda menu 
18) Display Dashboard on the Add Agenda Village Admin menu

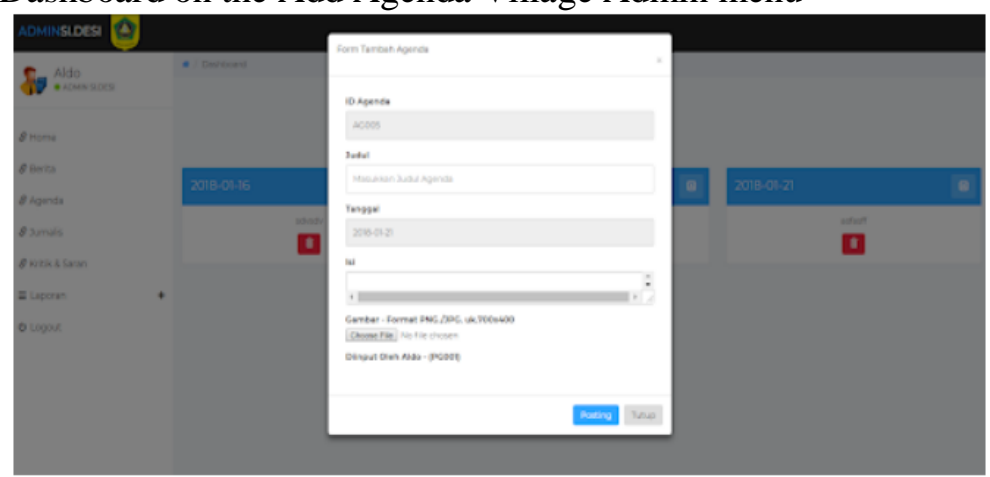

Figure 18. Add Agenda Village Admin menu

19) Display Dashboard on the Admin Journalist menu

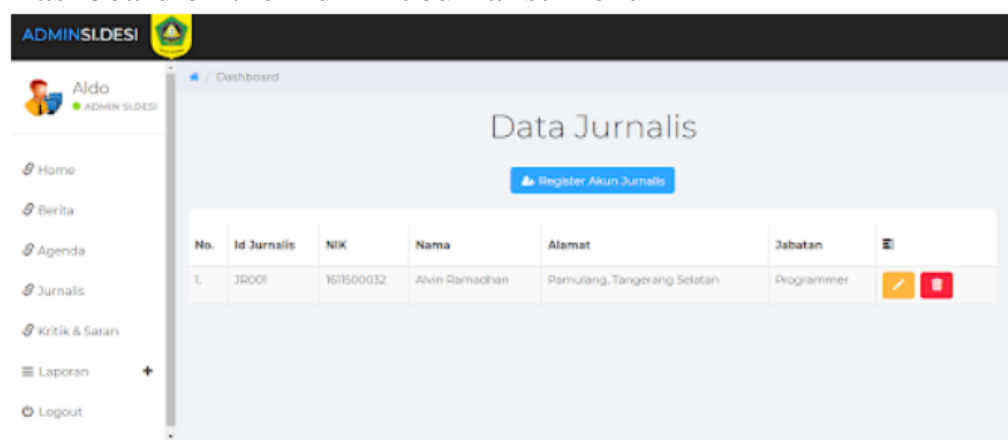

Figure 19. Admin Journalist menu

20) Display Dashboard on the Add Admin Journalist menu

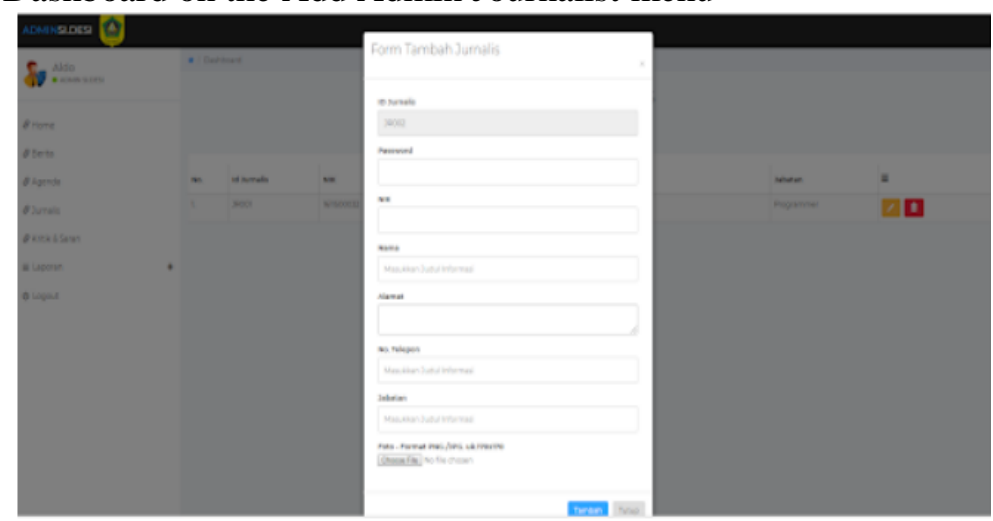

Figure 20. Admin Journalist menu

21) Display Dashboard on the Home Journalist menu

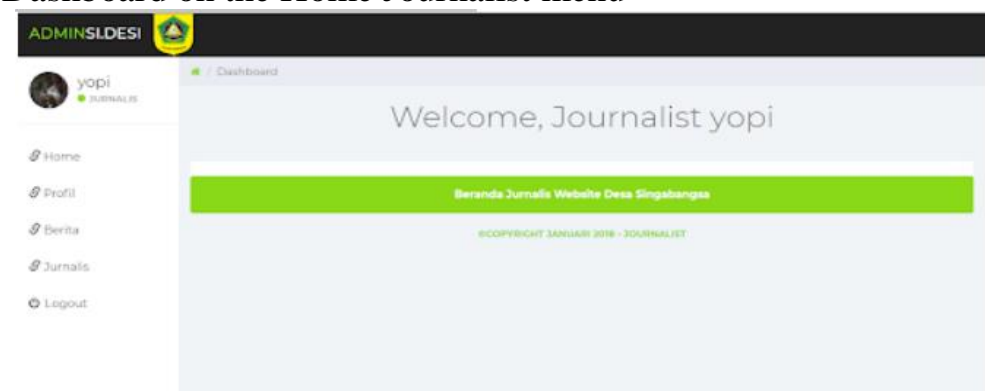

Figure 21. Home Journalist menu 
22) Display Dashboard on the Journalists Profile menu

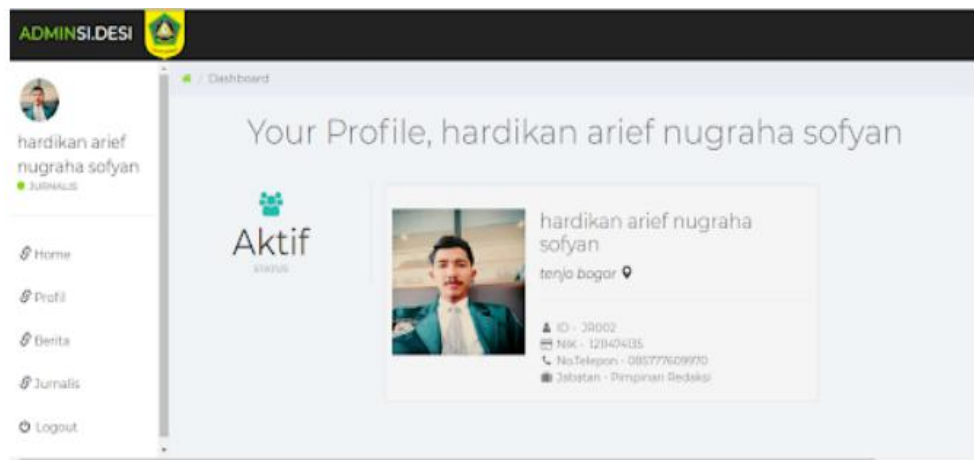

Figure 22. Journalists Profile menu

23) Display Dashboard on the Journalists News menu

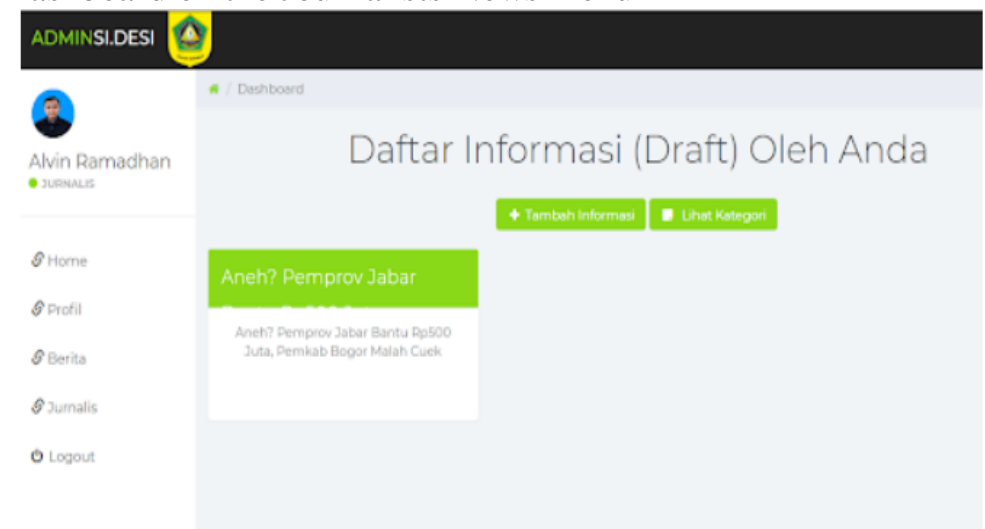

Figure 23. Journalists News menu

24) Display Dashboard on the Add Journal News Draft menu

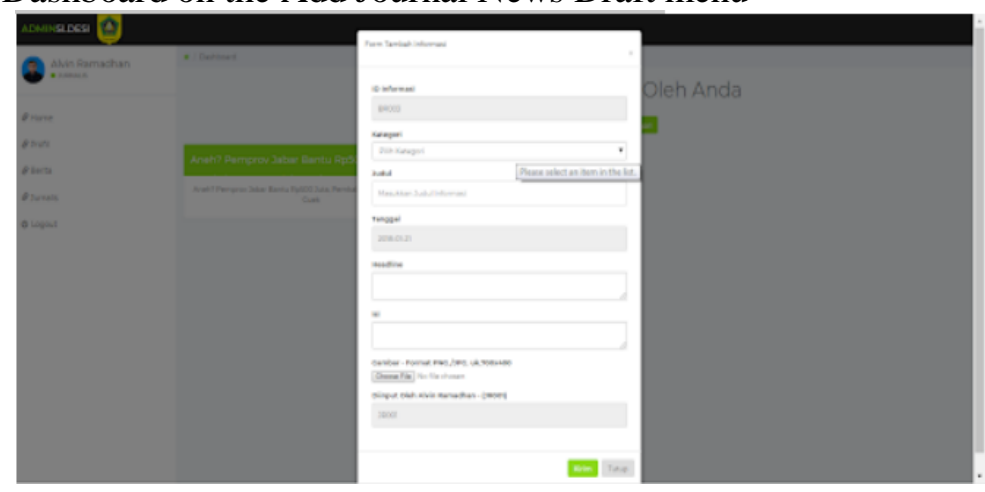

Figure 24. Add Journal News Draft menu 
25) Display Dashboard on the Journalists News Categories menu

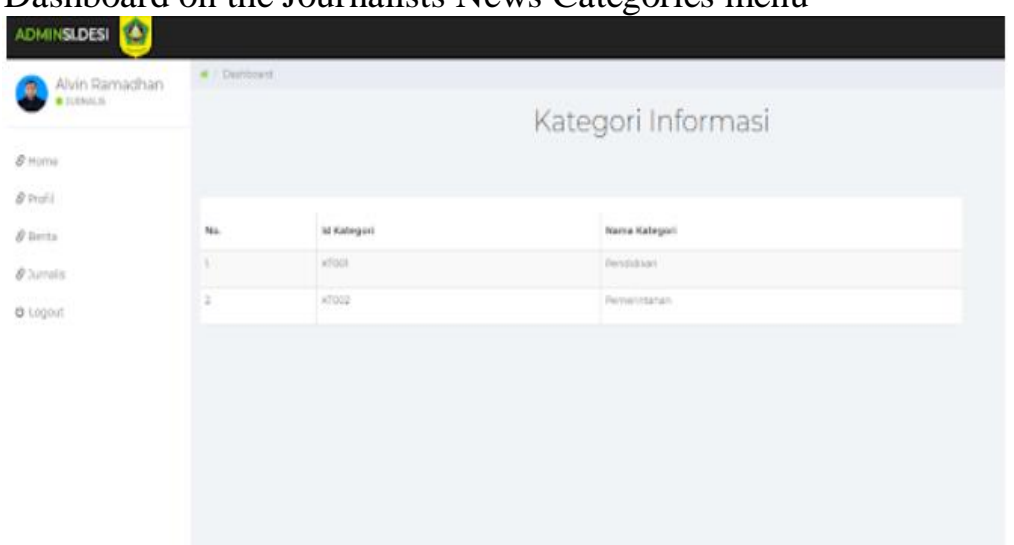

Figure 25. Journalists News Categories menu

\section{CONCLUSION}

1. Maplop transaction data processing system teller is currently running at PT Bank Tabungan Negara (pesero) Tbk, Karawaci Branch Office is still done manually, this causes less effective and efficient so it requires a long time for data searching and reporting.

2. With the computerized maplop transaction teller data processing system, it can make it easier for employees to do data collection, search up to report generation, so that a better, more effective and efficient job can be created.

\section{SUGGESTED}

1. It is necessary to train human resources in the field of computers to operate a system that is made so that errors do not occur.

2. There is regular back up and maintenance must be done to support the system's performance running well and in accordance with its functions and benefits.

\section{REFERENCES}

[1.] Mubarok, M. H., Nugroho, H. A., \& Nugroho, E. (2015). LANDASAN HUKUM DAN KESESUAIAN KETERBUKAAN DESA DENGAN SISTEM INFORMASI DESA BERBASIS OPEN GOVERNMENT DATA. SEMNASKIT POLITEKNIK NEGERI JEMBER.

[2.] Herlian, E. (2014). Perancangan sistem informasi data kependudukan pada kelurahan Kutabaru Kabupaten Tangerang Berbasis Web. Tangerang: Stmik Raharja.

[3.] Abbas, C. J., Kom, M., \& Panji Novantara, M. T. (2016). Rancang Bangun Sistem Informasi Kecamatan Berbasis E-Government. JEJARING, 1(01).

[4.] Ramadhani, Y., Alim, M. S., Eko, M. A., Fadli, A., \& Supriyanti, R. (2015). PENGEMBANGAN SISTEM INFORMASI DESA TERPADU BERBASIS WEB APLIKASI PADA DESA SIDAKANGEN, KAB. PURBALINGGA. Telematika, 8(1).

[5.] Sugianur, S., \& Nurcahyanti, Y. (2017). Sistem Informasi Pendataan Penduduk Desa Ganepo Berbasis Dekstop. Jurnal Penelitian Dosen FIKOM (UNDA), 3(1).

[6.] Seetharaman, P. (2017, March). Technology governance challenges in e-government projects: health information systems in India. In Proceedings of the 10th International Conference on Theory and Practice of Electronic Governance (pp. 504-507). 
[7.] Setiawan, A., \& Irawan, D. (2017). IMPLEMENTASI E-GOVERMENT SEBAGAI UPAYA PENINGKATAN POTENSI DESA DI SUKOHARJO. PROCIDING KMSI, $5(1)$. 